\title{
Tumour Budding Correlates with Aggressiveness of Cutaneous Squamous-cell Carcinoma
}

\author{
GEORGIA KARAYANNOPOULOU ${ }^{1}$, SYLVIE EUVRARD $^{2}$ and JEAN KANITAKIS ${ }^{2,3}$ \\ ${ }^{1}$ Department of Pathology, Aristotelian University of Thessaloniki, Thessaloniki, Greece; \\ Departments of ${ }^{2}$ Dermatology, and ${ }^{3}$ Pathology, Edouard Herriot Hospital Group, Lyon, France
}

\begin{abstract}
Background/Aim: Tumour budding (TB) is a specific pathological feature that has been found to be associated with an aggressive outcome in several cancer types; however, to our knowledge, TB has not yet been assessed in squamous-cell carcinomas of the skin (SCC). The aim of the study was to study whether TB correlates with aggressiveness in cutaneous SCC. Materials and Methods: We examined 31 aggressive SCC (that later developed local recurrences or metastases) in comparison with 21 nonaggressive SCC (not complicated by recurrence or metastasis). TB was expressed as the mean number of tumour buds in five adjacent high-power fields of each SCC. Results: Aggressive SCC had a much higher TB score compared to control SCC $(1.63 \pm 1.35$ vs. $0.49 \pm 0.9, p<0.001)$. Conclusion: As with other cancer types, TB seems to be a pathological marker of aggressiveness of cutaneous SCC, along with other features known to be associated with an aggressive outcome (tumour thickness, level of invasion and lymphovascular or perineural invasion). Further studies including a larger number of tumours will hopefully validate $T B$ as a new pathological predictor of aggressiveness in cutaneous SCC and will allow its correlation with other pathological features of SCC aggressiveness to be defined.
\end{abstract}

Tumour budding (TB) is defined as the process during which single cells, or small groups of neoplastic cells, detach from the main tumour mass in the invasive front and infiltrate the surrounding connective tissue. This feature is associated with an epithelial-mesenchymal transition, i.e. acquisition of a mesenchymal phenotype by neoplastic cells, enabling them

Correspondence to: J. Kanitakis, Department of Dermatology, Edouard Herriot Hospital (Pav. R), 69437 Lyon cedex 03, France. Tel: +33 472110301, Fax: +33 472110323, e-mail jean.kanitakis@univlyon1.fr

Key Words: Tumour budding, squamous-cell carcinoma, skin, aggressiveness, recurrence, metastasis. to infiltrate the connective tissue surrounding the neoplasm, penetrate into vascular spaces, and thereby reach distant tissues where they settle down and create a distant metastasis (1-4). The process of TB has been recognized as a feature of adverse tumour outcome, as it has been found to correlate with lymphovascular invasion, lymph node and distant metastasis, and decreased patient survival in several solid cancer types, including those of the colon (2-6), oesophagus $(5,8)$, pancreatic duct $(9,10)$, lung $(11)$, gallbladder $(12)$, head and neck (13), tongue (14-16), oral cavity (17-18), external auditory canal $(19)$, breast $(20,21)$ endometrium (22) and stomach (23). TB has been extensively studied in these carcinoma types, and inclusion of this pathological feature in pathological reports has been suggested $(2,3)$.

Squamous-cell carcinomas (SCC) of the skin are the second most common type of skin malignancy in the population at large, next only to basal-cell carcinomas (2428 ), and the commonest malignancy in organ-transplant recipients (OTR), in whom they entail significant morbidity and non-negligible mortality (29-31). Although cutaneous SCCs can usually be cured with surgical excision with adequate margins, some of them have an aggressive course, causing local recurrences and metastases (regional or distant). These events occur in 3-8\% and $1.9-10 \%$ of cases, respectively (30-32), and result in a mortality rate of $2-5 \%$ $(32,33)$. Several pathological features are recognized as being associated with an aggressive outcome of SCC, i.e. the development of recurrence and metastases and disease-specific death; they include macroscopic (horizontal) size $>2 \mathrm{~cm}$, microscopic thickness $>2 \mathrm{~mm}$, Clark level of invasion $\geq \mathrm{IV}$, involvement of deep tissues beyond the subcutaneous fat, poor differentiation and intravascular and perineural invasion (34-41). However, the prognostic significance of TB has not yet been studied in SCC of the skin.

The aim of this study was to assess a possible association of TB with SCC aggressiveness. In order to do so, we compared TB in two groups of SCCs (aggressive and nonaggressive) that were excised from a group of OTR followed up by our Dermatology Department. 


\section{Materials and Methods}

Study design. A retrospective pathological study was performed on biopsy or excision specimens of 31 aggressive SCC that had been excised from a group of OTR followed-up at our specialized outpatient dermatology clinic and that proved upon further followup to have an aggressive behaviour, defined as the development of local recurrences or regional or distant metastases, despite an initial surgical excision with tumour-free margins. They included 17 SCCs with subsequent local recurrence and 14 with subsequent metastases (10 to the lymph nodes, six in-transit and four distant, some SCCs developed metastases at more than one site). The skin SCCs were located on the head and neck in $61 \%$, the limbs in $33 \%$ and the trunk in $6 \%$. For those that had undergone multiple excisions (because of recurrences), only the initial tumour was examined. Control SCC consisted of 21 SCCs excised from the same group of patients during the 6 months preceding or following excision of the aggressive SCC, matched (whenever possible) for the anatomical location; these non-aggressive SCC had not develop recurrence or metastases during the same follow-up period as that of the aggressive SCC.

Assessment of TB. Representative haematoxylin-eosin-stained sections of each SCC were re-examined by one of us (GK) in a blind fashion as to the outcome of the SCC (aggressive or not) for evaluating the degree of TB. The sections were first examined at low magnification to assess the most invasive areas of each tumour. Thereafter the slides were examined at high magnification $(\times 250)$ and the number of tumour buds (single cells or groups of up to five malignant cells) in five adjacent microscopic fields was counted. The mean number of tumour buds per high-power field of each SCC, and then per group of SCC (aggressive and non-aggressive) was calculated. Statistical comparison between the two groups was carried out with Student's $t$-test, with a $p$-value of 0.05 or less considered statistically significant.

\section{Results}

Tumour buds included single undifferentiated SCC cells or small buds consisting of fewer than five tumour cells. They were found in the dermis in close proximity to the invasive tumour front (Figure 1). The mean score of tumour budding of aggressive SCC and non-aggressive SCC was 1.63 \pm 1.35 and $0.49 \pm 0.9$, respectively. The difference proved statistically significant $(p<0.001$ with Student's $t$-test).

\section{Discussion}

TB refers to the presence of clusters of undifferentiated malignant cells in the tumour stroma, located ahead of the invasive front of a tumour (1). TB is nowadays regarded as a pathological feature predictive of poor outcome in several types of cancer, including those of the colon, oesophagus, pancreatic duct, lung, gallbladder, head and neck, tongue, oral SCC, external auditory canal, breast, endometrium and stomach [reviewed in (1)]. Indeed, despite the lack of a universally accepted method of counting TB, studies performed with various methods have almost invariably shown that the degree of TB correlates positively with lymphovascular invasion, recurrence, lymph node metastasis, distant metastasis and poorer patient disease-free and overall survival in several cancer types. TB has mostly been studied in colorectal cancer and is considered by the Union for International Cancer Control as an additional prognostic factor (42), correlated with locoregional and distant (mostly liver) recurrence and lower 5-year survival. TB also correlates in colorectal cancer with other factors linked to poor prognosis, such as overall stage, T-stage, N-stage, Dukes' stage, tumour dedifferentiation, infiltrative growth pattern, lymphovascular and perineural invasion, nodal and distant metastasis (1).

Several methods have been applied to study TB. The initial definition of tumour buds included groups of up to four tumour cells (43), however, the actual trend is to consider groups of up to five cells (3), and this value was used in our study. We chose to use a quantitative method for TB counting (6) because this has proven to be the most effective in colorectal cancer (44) and has shown good interobserver reproducibility (45). Furthermore, recent studies suggest that TB should better be assessed as a continuous variable, rather than considering classes defined by cut-off values $(3,45)$. In our study, TB was readily performed on routinely stained tissue sections and it was not necessary to use immunohistochemical staining with antibodies against keratins, which can improve the detection of neoplastic cells (46). Using this methodology, we found that aggressive SCC had a significantly higher TB score compared with their nonaggressive counterparts, suggesting that TB correlates with aggressiveness (development of recurrence and metastases) of cutaneous SCC. This finding is not really unexpected, since the degree of TB has been shown to be predictive of an adverse outcome of SCC of other organs, such as the lungs (11), external auditory canal (19) and oral cavity and tongue $(13,14,16-18)$.

Several pathological variables have been shown to have a prognostic significance in cutaneous SCC, including microscopic tumour thickness, degree of differentiation, and lymphovascular, perineural and deep-tissue invasion (41). In a previous study, we examined these features in the same groups of tumours as those used in the present study, and found that although the two SCC groups (aggressive and non-aggressive) differed with respect to most of these pathological features, the only statistically significant difference was the invasion level (Clark) (47). This is probably due to the low power of the study because of the limited number of SCC studied. The findings of our present study suggest that TB could be a more sensitive predictor of adverse outcome in cutaneous SCC than the usual pathological features of aggressiveness used to date. The more precise relation of TB with these pathological features is currently under investigation. 


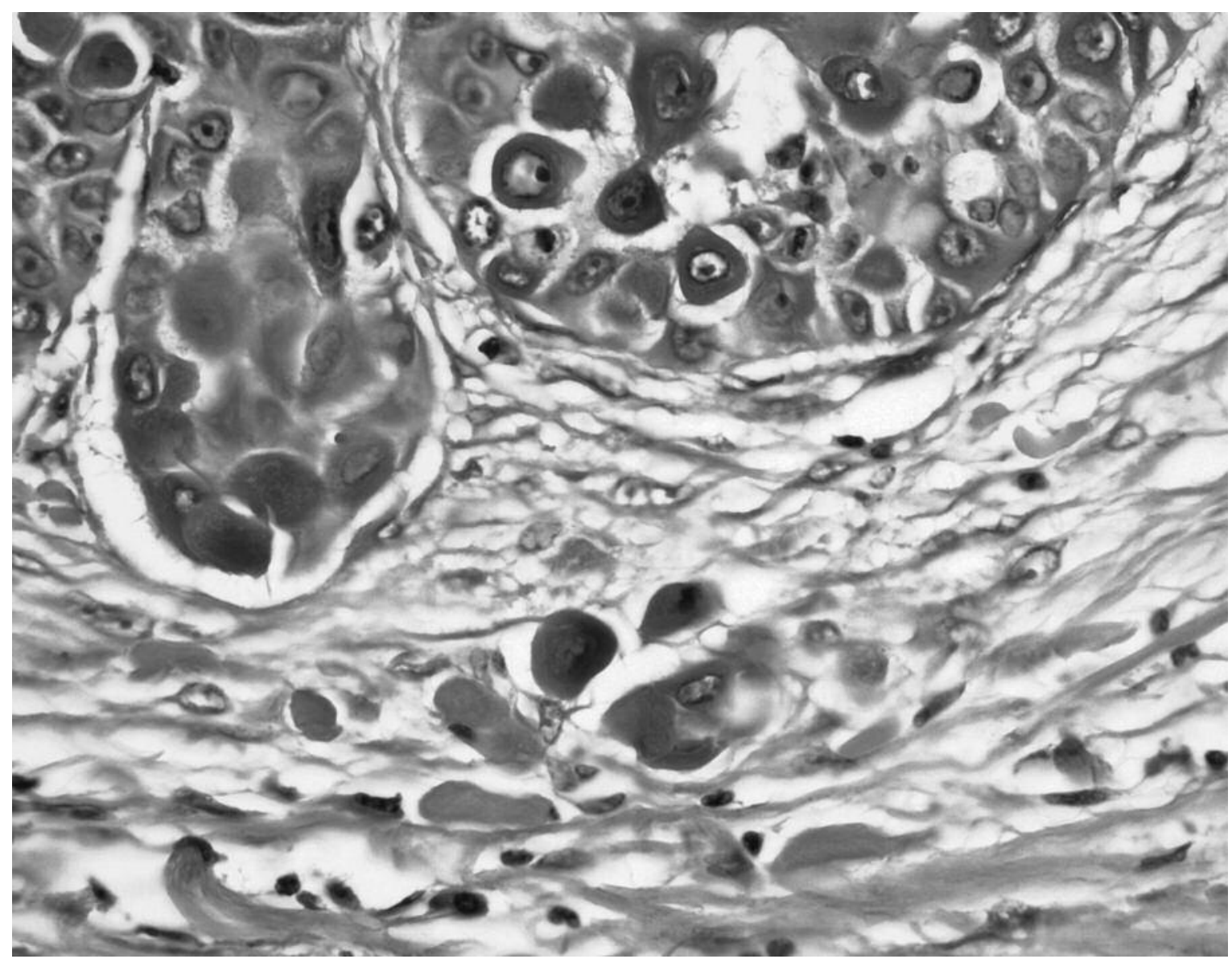

Figure 1. Tumour budding in an aggressive cutaneous squamous-cell carcinoma: several isolated tumour cells and small buds are seen in the dermis, ahead of the invasive front of the tumour (haematoxylin-eosin staining, magnification $\times 250$ ).

The possibility of depicting early (i.e. at the time of initial excision) SCC which are at higher risk for developing local recurrence and metastases is important for adequate patient management, especially in immunocompromised patients, in whom cutaneous SCC may be more aggressive. The results of our study suggest that similar to other cancer types, TB is a significant predictor of the development of recurrence and (locoregional or distant) metastases in cutaneous SCC. Our results should be confirmed by additional studies including a higher number of SCC from the general population and by further assessing whether $\mathrm{TB}$ correlates more with recurrence, metastasis, or disease-specific death in SCC. The inclusion of the degree of TB in pathological reports of cutaneous SCC will facilitate such retrospective studies.

\section{Conflicts of Interest}

The Authors declare that they have no conflict of interest.

\section{Funding}

None.

\section{References}

1 Grigore AD, Jolly MK, Jia D, Farach-Carson MC and Levine H: Tumor budding: The name is EMT. Partial EMT. J Clin Med 5(5): pii: E51. 2016.

2 De Smedt L, Palmans S and Sagaert X: Tumour budding in colorectal cancer: What do we know and what can we do? Virchows Arch 468: 397-408, 2016.

3 Koelzer V, Zlobec I and Lugli A: Tumor budding in colorectal cancer - Ready for diagnostic practice? Hum Pathol 47: 4-19, 2016.

4 Van Wyk HC, Park J, Roxburgh C, Horgan P, Foulis A and McMillan DC: The role of tumour budding in predicting survival in patients with primary operable colorectal cancer: A systematic review. Cancer Treat Rev 41: 151-159, 2015. 
5 Koelzer VH, Langer R, Zlobec I and Lugli A: Tumor budding in upper gastrointestinal carcinomas. Front Oncol 4: 216, 2014.

6 Wang LM, Kevans D, Mulcahy H, O'Sullivan J, Fennelly D, Hyland J, O'Donoghue D and Sheahan K: Tumor budding is a strong and reproducible prognostic marker in T3N0 colorectal cancer. Am J Surg Pathol 33: 134-141, 2009.

7 Almangush A, Karhunen M, Hautaniemi S, Salo T and Leivo I: Prognostic value of tumour budding in oesophageal cancer: a meta-analysis. Histopathology 68: 173-182, 2016.

8 Thies S, Guldener L, Slotta-Huspenina J, Zlobec I, Koelzer VH, Lugli A, Kröll D, Seiler CA, Feith M and Langer R: Impact of peritumoral and intratumoral budding in esophageal adenocarcinomas. Hum Pathol 52: 1-8, 2016.

9 Zhang L, Guo L, Tao M, Fu W and Xiu D: Parasympathetic neurogenesis is strongly associated with tumor budding and correlates with an adverse prognosis in pancreatic ductal adenocarcinoma. Chin J Cancer Res 28: 180-186, 2016.

10 O'Connor K, Li-Chang H, Kalloger S Peixoto RD, Webber DL, Owen DA, Driman DK, Kirsch R, Serra S, Scudamore CH, Renouf DJ and Schaeffer DF: Tumor budding is an independent adverse prognostic factor in pancreatic ductal adenocarcinoma. Am J Surg Pathol 39: 472-478, 2015.

11 Masuda R, Kijima H, Imamura N, Aruga N, Nakamura Y, Masude D, Takeichi H, Kato N, Nakagawa T, Tanaka M, Inokuchi $\mathrm{S}$ and Iwazaki $\mathrm{M}$ : Tumor budding is a significant indicator of a poor prognosis in lung squamous cell carcinoma patients. Mol Med Rep 6: 937-943, 2012.

12 Kai K, Kohya N, Kitahara K, Masuda M, Miyoshi A, Ide T, Tokunaga O, Miyazaki K and Noshiro H: Tumor budding and dedifferentiation in gallbladder carcinoma: potential for the prognostic factors in T2 lesions. Virchows Arch 459: 449-456, 2011.

13 Almangush A, Salo T, Hagström J and Leivo I: Tumour budding in head and neck squamous cell carcinoma - a systematic review. Histopathology 65: 587-594, 2014.

14 Seki M, Sano T, Yokoo S and Oyama T: Histologic assessment of tumor budding in preoperative biopsies to predict nodal metastasis in squamous cell carcinoma of the tongue and floor of the mouth. Head Neck 38(Suppl 1): E1582-1590, 2015.

15 Almangush A, Coletta RD, Bello IO, Bitu C, Keski-Säntti H, Mäkinen LK, Kauppila JH, Pukkila M, Hagström J, Laranne J, Tommola S, Soini Y, Kosma VM, Koivunen P, Kowalski LP, Nieminen P, Grénman R, Leivo I and Salo T: A simple novel prognostic model for early-stage oral tongue cancer. Int J Oral Maxillofac Surg 44: 143-150, 2015.

16 Xie N, Wang C, Liu X, Li R, Hou J, Chen X and Huang H: Tumor budding correlates with occult cervical lymph node metastasis and poor prognosis in clinical early-stage tongue squamous cell carcinoma. J Oral Pathol Med 44: 266-272, 2015.

17 Attramadal CG, Kumar S, Boysen ME, Dhakal HP, Nesland JM and Bryne M: Tumor budding, EMT and cancer stem cells in T1-2/N0 oral squamous cell carcinomas. Anticancer Res 35: 6111-6120, 2015.

18 Sawazaki-Calone I, Rangel A, Bueno AG, Morais CF, Nagai HM, Kunz RP, Souza RL, Rutkauskis L, Salo T, Almangush A and Coletta RD: The prognostic value of histopathological grading systems in oral squamous cell carcinomas. Oral Dis 21: 755-761, 2015.

19 Okado Y, Aoki M, Hamasaki M, Koga K, Sueta T, Shiratsuchi $\mathrm{H}$, Oda Y, Nakagawa $\mathrm{T}$ and Nabeshima K: Tumor budding and laminin $5-\gamma 2$ in squamous cell carcinoma of the external auditory canal are associated with shorter survival. Springer Plus 4: 814, 2015.

20 Liang F, Cao, W, Wang Y, Li L, Zhang G and Wang Z: The prognostic value of tumor budding in invasive breast cancer. Pathol Res Pract 209: 269-275, 2013.

21 Gujam F, McMillan D, Mohammed Z, Edwards J and Going J: The relationship between tumour budding, the tumour microenvironment and survival in patients with invasive ductal breast cancer. Br J Cancer 113: 1066-1074, 2015.

22 Koyuncuoglu M, Okyay E, Saatli B, Olgan S, Akin M and Saygili U: Tumor budding and E-Cadherin expression in endometrial carcinoma: Are they prognostic factors in endometrial cancer? Gynecol Oncol 125: 208-213, 2012.

23 Gabbert HE, Meier S, Gerharz, CD and Hommel G: Tumor-cell dissociation at the invasion front: A new prognostic parameter in gastric cancer patients. Int J Cancer 50: 202-207, 1992.

24 Rogers HW, Weinstock MA, Feldman SR and Coldiron BM: Incidence estimate of nonmelanoma skin cancer (keratinocyte carcinomas) in the U.S. population, 2012. JAMA Dermatol 151: 1081-1086, 2015.

25 Abbas $M$ and Kalia S: Trends in non-melanoma skin cancer (basal cell carcinoma and squamous cell carcinoma) in Canada: a descriptive analysis of available data. J Cutan Med Surg 20: 166-175, 2016.

26 Gandhi SA and Kampp J: Skin cancer epidemiology, detection, and management. Med Clin North Am 99: 1323-1335, 2015.

27 Lomas A, Leonardi-Bee J and Bath-Hextall F: A systematic review of worldwide incidence of nonmelanoma skin cancer. $\mathrm{Br}$ J Dermatol 166: 1069-1080, 2012.

28 Leiter U, Eigentler T and Garbe C: Epidemiology of skin cancer. Adv Exp Med Biol 810: 120-140, 2014.

29 Euvrard S, Kanitakis J and Claudy A: Skin cancers after organ transplantation. N Engl J Med 348: 1681-1691, 2003.

30 Ulrich C, Kanitakis J, Stockfleth E and Euvrard S: Skin cancer in organ transplant recipients - Where do we stand today? Am J Transplant 8: 2192-2198, 2008.

$31 \mathrm{Kim}$ C, Cheng J and Colegio OR: Cutaneous squamous cell carcinomas in solid organ transplant recipients: emerging strategies for surveillance, staging, and treatment. Semin Oncol 43: 390-394, 2016.

32 Brantsch KD, Meisner C, Schönfisch B, Trilling B, WehnerCaroli J, Röcken M and Breuninger H: Analysis of risk factors determining prognosis of cutaneous squamous-cell carcinoma: a prospective study. Lancet Oncol 9: 713-720, 2008.

33 Brougham N, Dennett E, Cameron R and Tan S: The incidence of metastasis from cutaneous squamous cell carcinoma and the impact of its risk factors. J Surg Oncol 106: 811-815, 2012.

34 Schmults C, Karia P, Carter J, Han J and Qureshi A: Factors predictive of recurrence and death from cutaneous squamous cell carcinoma. A 10-year, single-institution cohort study. JAMA Dermatol 149: 541-547, 2013.

35 Clayman G, Lee J, Holsinger F, Zhou X, Duvic M, El-Naggar AK, Prieto VG, Altamirano E, Tucker SL, Strom SS, Kripke ML and Lippman SM: Mortality risk from squamous cell skin cancer. J Clin Oncol 23: 759-765, 2005.

36 Farasat S, Yu S, Neel V, Nehal KS, Lardaro T, Mihm MC, Byrd DR, Balch CM, Califano JA, Chuang AY, Sharfman WH, Shah JP, Nghiem P, Otley CC,Tufaro AP, Johnson TM, Sober AJ and Liégeois NJ: A new American Joint Committee on Cancer 
staging system for cutaneous squamous cell carcinoma: Creation and rationale for inclusion of tumor (T) characteristics. J Am Acad Dermatol 64: 1051-1059, 2011.

37 Carter J, Johnson M, Chua T, Pritesh K and Schmults C: Outcomes of primary cutaneous squamous cell carcinoma with perineural invasion: An 11-year cohort study. JAMA Dermatol 149: 35-41, 2013.

38 Mullen J, Feng L, Xing Y, Mansfield PF, Gershenwald JE, Lee JE, Ross MI and Cormier JN: Invasive squamous cell carcinoma of the skin - defining a high-risk group. Ann Surg Oncol 13: 902-909, 2006.

39 Krediet JT, Beyer M, Lenz K, Ulrich C, Lange-Asschenfeldt B, Stockfleth E, Terhorst D: Sentinel lymph node and risk factors for predicting metastasis in cutaneous squamous cell carcinoma. Br J Dermatol 172: 1029-1036, 2015.

40 Ribero S, Osella Abate S, Di Capua C, Dika E, Balagna E, Senetta R, Picciotto F, Tomasini C, Macripo G and Quaglino P: Squamocellular carcinoma of the skin: clinicopathological features predicting the involvement of the surgical margins and review of the literature. Dermatology 232: 279-284, 2016.

41 Thompson A, Kelley B, Prokop L, Murad H and Baum C. Risk Factors for Cutaneous squamous cell carcinoma recurrence, metastasis, and disease-specific death. A systematic review and meta-analysis. JAMA Dermatol 152: 419-428, 2016.

42 Schmoll HJ, Van Cutsem E, Stein A, Valentini V, Glimelius B, Haustermans K, Nordlinger B, van de Velde CJ, Balmana J, Regula J, Nagtegaal ID, Beets-Tan RG, Arnold D, Ciardiello F, Hoff P, Kerr D, Köhne CH, Labianca R, Price T, Scheithauer W, Sobrero A, Tabernero J, Aderka D, Barroso S, Bodoky G, Douillard JY, El Ghazaly H, Gallardo J, Garin A, Glynne-Jones R, Jordan K, Meshcheryakov A, Papamichail D, Pfeiffer P, Souglakos I, Turhal S and Cervantes A: ESMO Consensus Guidelines for management of patients with colon and rectal cancer. A personalized approach to clinical decision making. Ann Oncol 23: 2479-2516, 2012.
43 Ueno H, Murphy J, Jass JR, Mochizuki H and Talbot IC: Tumour "budding" as an index to estimate the potential of aggressiveness in rectal cancer. Histopathology 40: 127-132, 2002.

44 Puppa G, Senore C, Sheahan K, Vieth M, Lugli A, Zlobec I, Pecori S, Wang LM, Langner C, Mitomi H, Nakamura T, Watanabe M, Ueno H, Chasle J, Conley SA, Herlin P, Lauwers GY and Risio M: Diagnostic reproducibility of tumour budding in colorectal cancer: A multicentre, multinational study using virtual microscopy. Histopathology 61: 562-575, 2012.

45 Horcic M, Koelzer VH, Karamitopoulou E, Terracciano L, Puppa G, Zlobec I and Lugli A: Tumor budding score based on 10 high-power fields is a promising basis for a standardized prognostic scoring system in stage II colorectal cancer. Hum Pathol 44: 697-705, 2013.

46 Kai K, Aishima S, Aoki S, Takase Y, Uchihashi K, Masuda M, Nishijima-Matsunobu A, Yamamoto M, Ide K, Nakayama A, Yamasaki $\mathrm{M}$ and Toda S: Cytokeratin immunohistochemistry improves interobserver variability between unskilled pathologists in the evaluation of tumor budding in $\mathrm{T} 1$ colorectal cancer. Pathol Int 66: 75-82, 2016.

47 Kanitakis J, Karayannopoulou G, Roux A and Euvrard S: Histopathological features predictive of aggressiveness of posttransplant cutaneous squamous cell carcinomas. Anticancer Res 35: 2305-2308, 2015.
Received June 30, 2016

Revised July 14, 2016

Accepted July 15, 2016 